Original Article

\title{
STABILITY INDICATING HPLC METHOD FOR DETERMINATION OF VILAZODONE HYDROCHLORIDE
}

\author{
BIRVA A. ATHAVIA*, ZARNA R. DEDANIA, RONAK R. DEDANIA, S. M. VIJAYENDRA SWAMY, CHETANA B. \\ PRAJAPATI
}

Bhagwan Mahavir College of Pharmacy (215), BMEF Campus, Bharthana, Vesu, Surat 395017

Email: birvaathavia@gmail.com

Received: 28 Jan 2017, Revised and Accepted: 20 Apr 2017

\begin{abstract}
Objective: The aim and objective of this study was to develop and validate Stability Indicating HPLC method for determination of Vilazodone Hydrochloride.

Methods: The method was carried out on a Phenomenex, $\mathrm{C}_{18}(250 \mathrm{x} 4.6 \mathrm{~mm}, 5 \mu \mathrm{m})$ Column using a mixture of Acetonitrile: Water (50:50v/v), pH adjusted to 3.3 with Glacial Acetic Acid for separation. The flow rate was adjusted at $1 \mathrm{ml} / \mathrm{min}$ and Detection was carried out at $240 \mathrm{~nm}$.

Results: The retention time of vilazodone hydrochloride was found to be $2.3 \mathrm{~min}$. The calibration curve was found to be linear in the range $25-$ $75 \mu \mathrm{g} / \mathrm{ml}$ with a correlation coefficient $\left(\mathrm{R}^{2}=0.996\right)$. The limit of detection and limit of quantitation were found to be $4.78 \mu \mathrm{g} / \mathrm{ml}$ and $14.48 \mu \mathrm{g} / \mathrm{ml}$ respectively. The $\%$ recovery of vilazodone hydrochloride was found to be in the range of $98.21 \pm 0.08 \%$ to $99.07 \pm 0.64 \%$. The proposed method was successfully applied for the estimation of vilazodone hydrochloride in marketed tablet formulation.
\end{abstract}

Vilazodone Hydrochloride was subjected to forced degradation under Acidic, Alkaline, Oxidation, Dry Heat and Photolytic degradation conditions. Vilazodone hydrochloride showed $3.12 \%$ degradation under acidic condition, $4.78 \%$ under alkaline condition, $7.8 \%$ under oxidation condition, $3.53 \%$ under dry heat condition and $4.9 \%$ under photolytic condition.

Acid degradation impurity was identified and characterised by LC-MS/MS was found to be 1-(4-Penten-1-yl) piperazine having molecular weight 154.253 (m/z 155.08) and Molecular Formula $\mathrm{C}_{9} \mathrm{H}_{18} \mathrm{~N}_{2}$.

Conclusion: A simple, precise, rapid and accurate Stability Indicating HPLC method has been developed and validated for the determination of Vilazodone Hydrochloride in presence of its degradation products as per the ICH Guidelines.

Keywords: Vilazodone Hydrochloride, HPLC, Stability Indicating Method, Acid Degradation Impurity

(C) 2017 The Authors. Published by Innovare Academic Sciences Pvt Ltd. This is an open access article under the CC BY license (http://creativecommons.org/licenses/by/4.0/) DOI: http://dx.doi.org/10.22159/ijcpr.2017v9i4.20975

\section{INTRODUCTION}

Vilazodone contains polymorph Form IV vilazodone hydrochloride for oral administration. Vilazodone belongs serotonergic antidepressant category. Vilazodone is an indole-piperazine derivative. It is a selective serotonin reuptake inhibitor (SSRI) and a 5 - $\mathrm{HT}_{1 \mathrm{~A}}$ receptor partial agonist. It has negligible affinity for other serotonin receptors. Vilazodone's antidepressant effects are thought to be due to the enhancement of serotonergic activity in the central nervous system (CNS) through selective inhibition of serotonin reuptake. Vilazodone Hydrochloride is indicated for the treatment of Major Depressive Disorder (MDD). It works by helping to restore the balance of serotonin in the brain. Vilazodone Hydrochloride is chemically 5-\{4-[4-(5-Cyano1H-indol-3-yl) butyl] piperazin-1-yl $\}$ benzofuran-2-carboxamide monohydrochloride [2] (fig. 1). Vilazodone Hydrochloride was approved by the FDA for the treatment of Major Depressive Disorder in January 2011. It is not official in any pharmacopoeia.

Stability is an essential factor for quality, safety and efficacy of a drug product. Literature search reveals that there are very few methods reported for the determination of Vilazodone Hydrochloride in different instrumental techniques like HPLC [3-6], UV [7], HPTLC [8], LC-ESIMS/MS [9], UPLC-MS/MS [10], LC-MS/MS [11], LC-PDA [12], etc. Literature Survey also revealed that few Stability Indicating HPLC methods have been reported for drugs like Aripiprazole [13], Quetiapine Fumarate [14], Risperidone [15] and other antipsychotic drugs.

The aim of present study was to develop and validate stability indicating HPLC method for determination of Vilazodone Hydrochloride. As compared to other analytical techniques, HPLC method is highly powerful, quick, automated, accurate, efficient, reproducible, sensitive and extremely precise analytical technique. Also, there is no official method for the estimation of Vilazodone Hydrochloride in the pharmacopoeia so it was thought to develop and validate a new simple, sensitive, reliable and reproducible stability indicating HPLC method for Vilazodone Hydrochloride and to identify and characterize acid degradant impurity of Vilazodone Hydrochloride.

\section{MATERIALS AND METHODS}

\section{Materials}

Pure sample of Vilazodone Hydrochloride was received from SYMED LABS LIMITED, Hyderabad as a gift sample. All Chemicals and Reagents used were of Analytical Grade and HPLC Grade. Marketed Formulation used for assay was Valz-20 by Torrent Pharmaceuticals Ltd, Ahmedabad; having Label Claim $20 \mathrm{mg}$ of Vilazodone Hydrochloride, Batch No. VAC51003, Mfg. OCT.2015, Exp. SEP.2017.

\section{Instruments}

The HPLC System used was Liquid Chromatograph: LC-2010 CHT (Shimadzu) with photodiode array detector and Class VP software. The column used was phenomenex, $\mathrm{C}_{18}(250 \times 4.6 ; 5 \mu \mathrm{m})$. The LC instrument used for LC-MS analysis was surveyor plus HPLC system with autosampler and PDA detector.

\section{Optimization of HPLC method}

\section{Optimization of Chromatographic condition}

Chromatographic separation was achieved on reversed phase column Phenomenex, $\mathrm{C}_{18}(250 \times 4.6 \mathrm{~mm}, 5 \mu \mathrm{m})$ using mobile phase 
Acetonitrile: Water (50:50, v/v), pH 3.3 adjusted with Glacial Acetic Acid at ambient temperature. The flow rate was $1 \mathrm{ml} / \mathrm{minute}$ and injection volume was $10 \mu \mathrm{l}$. The detection was carried out at $240 \mathrm{~nm}$.

\section{Validation of proposed HPLC method}

\section{Preparation of standard}

The standard stock solution of $1000 \mu \mathrm{g} / \mathrm{ml}$ was prepared by dissolving $50 \mathrm{mg}$ of Vilazodone Hydrochloride in $50 \mathrm{ml}$ mobile phase. The standard stock solution of $100 \mu \mathrm{g} / \mathrm{ml}$ was prepared by diluting $5 \mathrm{ml}$ of standard stock solution $(1000 \mu \mathrm{g} / \mathrm{ml})$ to $50 \mathrm{ml}$ with mobile phase.

\section{Linearity}

The linearity response was determined by preparing and injecting solutions with concentration about $25,37.5,50,62.5$ and $75 \mu \mathrm{g} / \mathrm{ml}$ prepared from standard stock solution $(100 \mu \mathrm{g} / \mathrm{ml})$ with mobile phase.

\section{Precision}

The injection system precision was determined by performing 6 replicate injection for Repeatability at $50 \mu \mathrm{g} / \mathrm{ml}$ and 3 replicate injections for Intra-day and Inter-day Precision at 37.5, 50 and $62.5 \mu \mathrm{g} / \mathrm{ml}$.

\section{Accuracy}

The accuracy of the method was confirmed by Recovery study from Marketed Formulation at three level of standard addition. The quantity of tablet powder equivalent to $10 \mathrm{mg}$ Vilazodone Hydrochloride was transferred to four individual $100 \mathrm{ml}$ volumetric flasks about $25 \mathrm{ml}$ of mobile phase were added and the flask was sonicated for $15 \mathrm{~min}$. The volume was made up to the mark with mobile phase and mixed well. The sample solutions were prepared by spiking known amount of Vilazodone Hydrochloride at 80\%, 100 $\%$ and $120 \%$ level to a pre-analyzed sample of Vilazodone Hydrochloride. The $5 \mathrm{ml}$ of above solution further diluted to $10 \mathrm{ml}$ with mobile phase. The $10 \mu \mathrm{l}$ was injected for HPLC analysis.

\section{Limit of detection (LOD) and limit of quantitation (LOQ)}

The LOD and LOQ for Vilazodone Hydrochloride were determined at a signal-to-noise ratio of 3:1 and 10:1 respectively by injecting a series of dilute solutions of known concentrations.

\section{Robustness}

Robustness of the method was determined by subjecting the method to a slight change in method condition using $50 \mu \mathrm{g} / \mathrm{ml}$ solution of Vilazodone Hydrochloride; by changing Pump Flow Rate and by changing $\mathrm{pH}$ of Mobile Phase and \% RSD was calculated.

\section{Assay}

20 tablets of Vilazodone Hydrochloride were weighed and powdered. The tablet powder equivalent to $10 \mathrm{mg}$ of Vilazodone Hydrochloride was accurately weighed and transferred to a $100 \mathrm{ml}$ volumetric flask, about $25 \mathrm{ml}$ of mobile phase was added and the flask was sonicated for $15 \mathrm{~min}$. The volume was made up to the mark with mobile phase and mixed well. The $5 \mathrm{ml}$ of above solution was diluted to $10 \mathrm{ml}$ with mobile phase. The $10 \mu \mathrm{l}$ of $50 \mu \mathrm{g} / \mathrm{ml}$ was injected for HPLC analysis.

\section{Forced degradation study}

\section{Preparation of standard solution}

The standard stock solution $100 \mu \mathrm{g} / \mathrm{ml}$ of Vilazodone Hydrochloride was prepared by dissolving accurately weighed $10 \mathrm{mg}$ of the drug, transferred to $100 \mathrm{ml}$ volumetric flask, dissolved and made up to the volume using mobile phase. The $5 \mathrm{ml}$ of above solution further diluted to $10 \mathrm{ml}$ with mobile phase to give $50 \mu \mathrm{g} / \mathrm{ml}$ solution.

\section{Acidic degradation}

Accurately weighed $10 \mathrm{mg}$ of Vilazodone Hydrochloride was transferred to $100 \mathrm{ml}$ volumetric flask. To the above $1 \mathrm{ml} 1 \mathrm{M} \mathrm{HCl}$ was added and $25 \mathrm{ml}$ mobile phase was added. The solution was refluxed for 1 hour at $80-100{ }^{\circ} \mathrm{C}$ in water bath. After that, the solution was cooled and neutralised by $1 \mathrm{ml} 1 \mathrm{M} \mathrm{NaOH}$ and the volume was made up to mark with mobile phase. Dilute $5 \mathrm{ml}$ of above solution with mobile phase up to $10 \mathrm{ml}$.

\section{Alkaline degradation}

Accurately weighed $10 \mathrm{mg}$ of Vilazodone Hydrochloride was transferred to $100 \mathrm{ml}$ volumetric flask. To the above $1 \mathrm{ml} 1 \mathrm{M} \mathrm{NaOH}$ was added and $25 \mathrm{ml}$ mobile phase was added. The solution was refluxed for 1 hour at $80-100{ }^{\circ} \mathrm{C}$ in water bath. After that, the solution was cooled and neutralised by $1 \mathrm{ml} 1 \mathrm{M} \mathrm{HCl}$ and the volume was made up to mark with the mobile phase. Dilute $5 \mathrm{ml}$ of above solution with mobile phase up to $10 \mathrm{ml}$.

\section{Oxidative degradation}

Accurately weighed $10 \mathrm{mg}$ of Vilazodone Hydrochloride was transferred to $100 \mathrm{ml}$ volumetric flask. To the above $1 \mathrm{ml} \mathrm{3} \% \mathrm{H}_{2} \mathrm{O}_{2}$ was added and $25 \mathrm{ml}$ mobile phase was added. The solution was refluxed for 1 hour at $80-100{ }^{\circ} \mathrm{C}$ in water bath. After that, the solution was cooled and the volume was made up to mark with the mobile phase. Dilute $5 \mathrm{ml}$ of above solution with mobile phase up to $10 \mathrm{ml}$.

\section{Dry Heat degradation}

Accurately weighed $10 \mathrm{mg}$ of Vilazodone Hydrochloride was taken in a porcelain dish and kept in hot air oven at $100^{\circ} \mathrm{C}$ for $6 \mathrm{~h}$. After that Vilazodone Hydrochloride was transferred into $100 \mathrm{ml}$ volumetric flask and volume was made up to the mark by mobile phase. Dilute $5 \mathrm{ml}$ of above solution with mobile phase up to $10 \mathrm{ml}$.

\section{Photolytic degradation}

Accurately weighed $10 \mathrm{mg}$ of Vilazodone Hydrochloride was taken in a porcelain dish with a closed lid and was exposed to sunlight in an open atmosphere for $24 \mathrm{~h}$. After that Vilazodone Hydrochloride was transferred into $100 \mathrm{ml}$ volumetric flask and volume were made up to the mark by mobile phase. Dilute $5 \mathrm{ml}$ of above solution with mobile phase up to $10 \mathrm{ml}$.

\section{Characterization of acid degradation impurity by LC-MS/MS}

LC-MS experiment was carried out on LCQ Fleet Ion Trap LC/MSn equipped with Entrap Triple Quadrupole Analyzer. The LC instrument used for LC-MS experiment was Surveyor plus HPLC System with Auto Sampler and PDA Detector. The analysis was carried out using Hypersil $\mathrm{C}_{18}(250 \times 4.6 \mathrm{~mm} ; 5 \mu \mathrm{m})$ column, using mobile phase Acetonitrile: Water (50:50; v/v) pH 3.3 adjusted with Glacial Acetic Acid at $240 \mathrm{~nm}$ detection wavelength, flow rate 1 $\mathrm{ml} / \mathrm{min}$, injection volume $10 \mu \mathrm{l}$. The Mass Spectra of Vilazodone Hydrochloride and its acid degradation product were recorded on LCQ Fleet Ion Trap LC/MSn mass spectrometer. The detection of ions was performed in Electron Spray Ionization positive ion mode. The data was collected and processed using Xcalibur software.

\section{RESULTS AND DISCUSSION}

\section{Optimisation of Chromatographic condition}

The chromatographic conditions were optimised with a view to developing a stability-indicating assay method. The method was optimized using Phenomenex, C18 (250x4.6 mm, $5 \mu \mathrm{m})$ using mobile phase Acetonitrile: Water (50:50, v/v), pH 3.3 adjusted with Glacial Acetic Acid at ambient temperature. The flow rate was $1 \mathrm{ml} / \mathrm{minute}$ and the injection volume was $10 \mu \mathrm{l}$. The detection was carried out at $240 \mathrm{~nm}$.

\section{Validation of proposed HPLC method}

\section{Linearity}

The linearity of Vilazodone Hydrochloride was determined in the concentration range of $25,37.5,50,62.5$ and $75 \mu \mathrm{g} / \mathrm{ml}$ by diluting stock solution. The calibration curve was found to be linear in this range. The correlation coefficient obtained was greater than 0.996 .

\section{Precision}

The \%RSD value of Vilazodone Hydrochloride for Repeatability was found to be $0.53 \%$, for Intra-Day Precision was found to be in the range $0.72-1.41 \%$ and for Inter-Day Precision was found to be in the 
range $0.47-0.80 \%$. The \%RSD value of Vilazodone Hydrochloride was found to be less than $2 \%$, which indicates that the developed method is precise.

\section{Accuracy}

The percentage recovery of Vilazodone Hydrochloride was found to be in range $98.21 \pm 0.08 \%-99.07 \pm 0.64 \%$.

\section{Limit of detection (LOD) and limit of quantitation (LOQ)}

The LOD and LOQ of Vilazodone Hydrochloride were found to be $4.78 \mu \mathrm{g} / \mathrm{ml}$ and $14.48 \mu \mathrm{g} / \mathrm{ml}$ respectively.

\section{Robustness}

Robustness of the method was determined by slightly changing the $\mathrm{pH}$ and the flow rate of mobile phase using $50 \mu \mathrm{g} / \mathrm{ml}$ solution of Vilazodone Hydrochloride. \% RSD was found to be in the range $0.22-0.98 \%$.

\section{Assay of marketed formulation}

The proposed method was successfully applied to the marketed tablet dosage form Valz-20 having a label claim $20 \mathrm{mg}$ of Vilazodone Hydrochloride. The \% Assay was found to be $98.09 \pm 1.22 \%$.

\section{Force degradation studies}

\section{Degradation under acidic condition}

After refluxing, the drug solution with $1 \mathrm{~N} \mathrm{HCl}$ at $80-100{ }^{\circ} \mathrm{C}$ for 1 hour, the percentage degradation of Vilazodone Hydrochloride in acidic condition was found to be $3.1 \%$.

\section{Degradation in alkaline condition}

After refluxing, the drug solution with $1 \mathrm{~N} \mathrm{NaOH}$ at $80-100{ }^{\circ} \mathrm{C}$ for 1 hour, the percentage degradation of Vilazodone Hydrochloride in alkaline condition was found to be $4.78 \%$.

\section{Oxidative degradation}

After refluxing the drug solution with $3 \%$ hydrogen peroxide at 80 $100{ }^{\circ} \mathrm{C}$ for 1 hour, the percentage degradation of Vilazodone Hydrochloride in Oxidative Condition was found to be $7.8 \%$.

\section{Dry heat degradation}

After exposing the drug powder to dry heat at $100{ }^{\circ} \mathrm{C}$ for $6 \mathrm{~h}$, the percentage degradation of Vilazodone Hydrochloride in Dry Heat condition was found to be $3.53 \%$.

\section{Photolytic degradation}

After exposing the drug powder to direct sunlight in petri dish covered with lid, the percentage degradation of Vilazodone Hydrochloride in Photolytic condition was found to be $4.9 \%$.

\section{Characterization of impurity by LC-MS/MS}

The base ion peak at retention time $3.44 \mathrm{~min}$ was $\mathrm{m} / \mathrm{z} 442.33$. The probable acid degradant with retention time 3.03 min showed base ion peak at $\mathrm{m} / \mathrm{z}$ 155.08. Acid degradation impurity was identified and characterised by LC-MS/MS was found to be 1-(4-Penten-1-yl) piperazine having Molecular Weight 154.253 (m/z 155.08) and molecular formula $\mathrm{C}_{9} \mathrm{H}_{18} \mathrm{~N}_{2}$.

Table 1: Linearity of vilazodone hydrochloride

\begin{tabular}{lll}
\hline S. No. & Concentration $(\boldsymbol{\mu g} / \mathbf{m l})$ & Peak area $(\mathbf{m e a n} \pm \mathbf{S D}) ;(\mathbf{n}=3)$ \\
\hline 1 & 25 & $2351891.33 \pm 11650.43$ \\
2 & 37.5 & $3756985.00 \pm 23711.85$ \\
3 & 50 & $4763628.00 \pm 40607.60$ \\
4 & 62.5 & $6124760.33 \pm 16316.36$ \\
5 & 75 & $7113593.33 \pm 115875.76$ \\
\hline
\end{tabular}

Table 2: Intra-day and Inter-day precision

\begin{tabular}{|c|c|c|c|c|c|}
\hline S. No. & Precision period & Concentration $(\mu \mathrm{g} / \mathrm{ml})$ & Mean $(n=3)$ & SD & \%RSD \\
\hline \multirow[t]{3}{*}{1} & Intra-Day Precision & 37.5 & 3728892.67 & 52723.83 & 1.41 \\
\hline & & 50 & 4694937.67 & 62944.68 & 1.34 \\
\hline & & 62.5 & 6187850.33 & 44314.56 & 0.72 \\
\hline \multirow[t]{3}{*}{2} & Inter-Day Precision & 37.5 & 3749863.33 & 30067.72 & 0.80 \\
\hline & & 50 & 4699207.00 & 22055.11 & 0.47 \\
\hline & & 62.5 & 6136864.67 & 34131.21 & 0.56 \\
\hline
\end{tabular}

Table 3: Results for recovery of vilazodone hydrochloride

\begin{tabular}{|c|c|c|c|c|c|c|c|}
\hline Level & $\begin{array}{l}\text { Amount } \\
\text { from the } \\
\text { sample(mg) }\end{array}$ & $\begin{array}{l}\text { Amount of standard } \\
\text { vilazodone spiked } \\
\text { (mg) }\end{array}$ & $\begin{array}{l}\text { Total } \\
\text { Amount } \\
\text { (mg) }\end{array}$ & Peak area & $\begin{array}{l}\text { Total amount } \\
\text { found (mg) }\end{array}$ & $\begin{array}{l}\text { Amount } \\
\text { recovered } \\
(\mathrm{mg}) \pm S D(n=3)\end{array}$ & $\begin{array}{l}\% \text { amount } \\
\text { recovered } \pm S D \\
(n=3)\end{array}$ \\
\hline Blank & 10 & - & 10 & $4731337.66 \pm 58029.53$ & $9.81 \pm 1.24$ & - & - \\
\hline $80 \%$ & 10 & 8 & 18 & $7739185 \pm 65986.01$ & $16.13 \pm 0.14$ & $7.90 \pm 0.05$ & $98.81 \pm 0.68$ \\
\hline $100 \%$ & 10 & 10 & 20 & $9443750.33 \pm 41570.78$ & $19.72 \pm 0.09$ & $9.91 \pm 0.06$ & $99.07 \pm 0.64$ \\
\hline $120 \%$ & 10 & 12 & 22 & $11457940.67 \pm 56480.16$ & $23.95 \pm 0.12$ & $11.78 \pm 0.01$ & $98.21 \pm 0.08$ \\
\hline
\end{tabular}

Table 4: Summary of validation parameters

\begin{tabular}{ll}
\hline Parameters & Results \\
\hline Linearity and Range & $25-75 \mu \mathrm{g} / \mathrm{ml}$ \\
Correlation Coefficient $\mathrm{R}^{2}$ & 0.996 \\
Regression Equation & $\mathrm{y}=95129 \mathrm{x}+65700$ \\
Repeatability (\%RSD) & $0.53 \%$ \\
Intra-Day Precision (\%RSD) & $0.72-1.41 \%$ \\
Inter-Day Precision (\%RSD) & $0.47-0.80 \%$ \\
Accuracy (\%) & $98.21 \pm 0.08 \%-99.07 \pm 0.64 \%$ \\
LOD $(\mu \mathrm{g} / \mathrm{ml})$ & $4.78 \mu \mathrm{g} / \mathrm{ml}$ \\
LOQ $(\mu \mathrm{g} / \mathrm{ml})$ & $14.48 \mu \mathrm{g} / \mathrm{ml}$ \\
Robustness (\%RSD) & $0.22-0.98 \%$ \\
Assay $(\%)$ & $98.09 \pm 1.22 \%$ \\
\hline
\end{tabular}


Table 5: Summary of degradation study under various stress condition

\begin{tabular}{|c|c|c|c|c|c|}
\hline $\begin{array}{l}\text { S. } \\
\text { No. }\end{array}$ & Exposure condition & & $\begin{array}{l}\text { Number of degradation } \\
\text { products }\left(t_{R}\right) \text { min }\end{array}$ & $\begin{array}{l}\text { \% Drug } \\
\text { recovered }\end{array}$ & $\begin{array}{l}\text { \% } \\
\text { degradation }\end{array}$ \\
\hline 1. & Acid Degradation & $1 \mathrm{~N} \mathrm{HCl}\left(1 \mathrm{~h}\right.$ Reflux at $\left.80-100^{\circ} \mathrm{C}\right)$ & $3(1.984,2.560,4.128)$ & $96.88 \%$ & $3.12 \%$ \\
\hline 2. & Alkaline Degradation & $1 \mathrm{~N} \mathrm{NaOH}\left(1 \mathrm{~h}\right.$ Reflux at $\left.80-100^{\circ} \mathrm{C}\right)$ & $4(2.517,3.115,4.053,5.056)$ & $95.22 \%$ & $4.78 \%$ \\
\hline 3. & Oxidative Degradation & $3 \% \mathrm{H}_{2} \mathrm{O}_{2}\left(1 \mathrm{~h}\right.$ Reflux at $\left.80-100{ }^{\circ} \mathrm{C}\right)$ & $3(1.920,2.763,4.032)$ & $92.2 \%$ & $7.8 \%$ \\
\hline 4. & Dry Heat Degradation & Dry Heat $\left(100^{\circ} \mathrm{C}, 6 \mathrm{~h}.\right)$ & $4(1.931,2.229,4.064,5.099)$ & $96.47 \%$ & $3.53 \%$ \\
\hline 5 & Photolytic Degradation & Photolytic (Sun Light, 24 h) & $4(1.920,2.123,4.053,5.120)$ & $95.1 \%$ & $4.9 \%$ \\
\hline
\end{tabular}

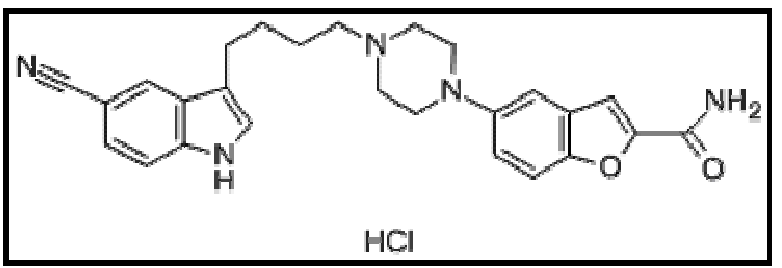

Fig. 1: Structure of vilazodone hydrochloride

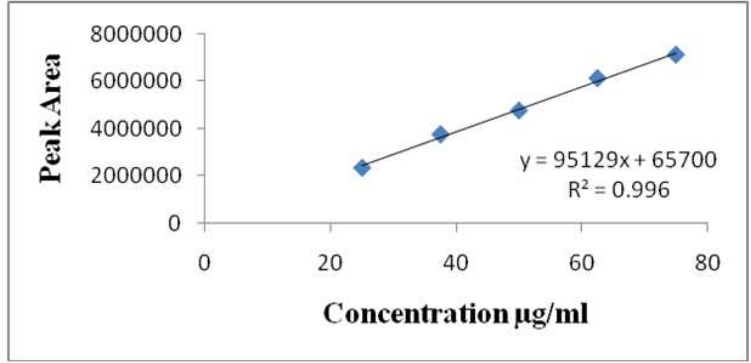

Fig. 2: Calibration curve for vilazodone hydrochloride $(25-75 \mu \mathrm{g} / \mathrm{ml})$

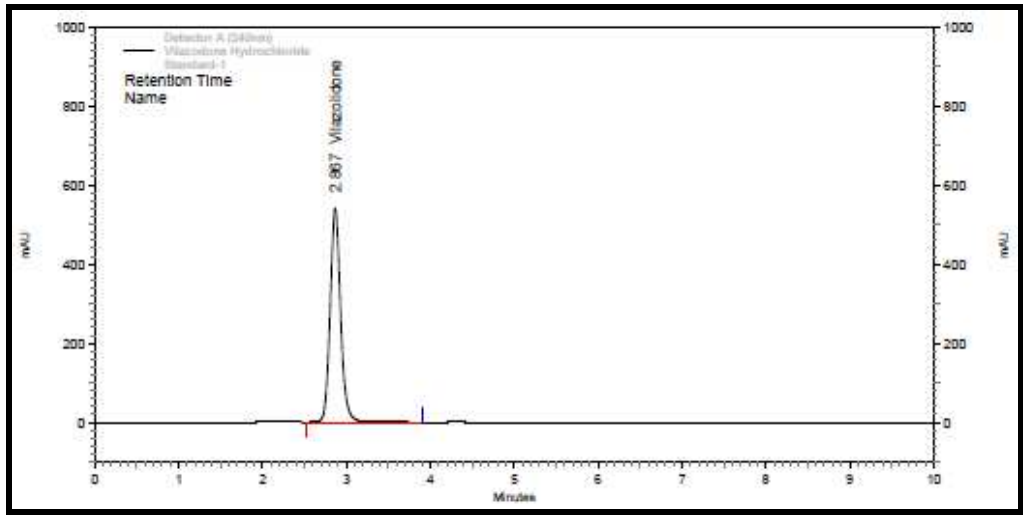

Fig. 3: Chromatogram of standard vilazodone hydrochloride $(50 \mu \mathrm{g} / \mathrm{ml})$

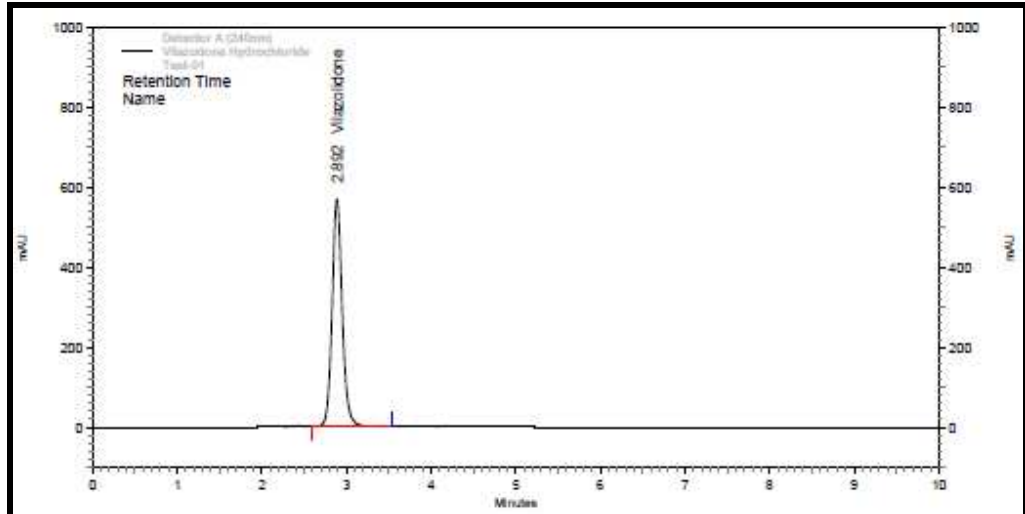

Fig. 4: Chromatogram of marketed formulation of vilazodone hydrochloride $(50 \mu \mathrm{g} / \mathrm{ml})$ 


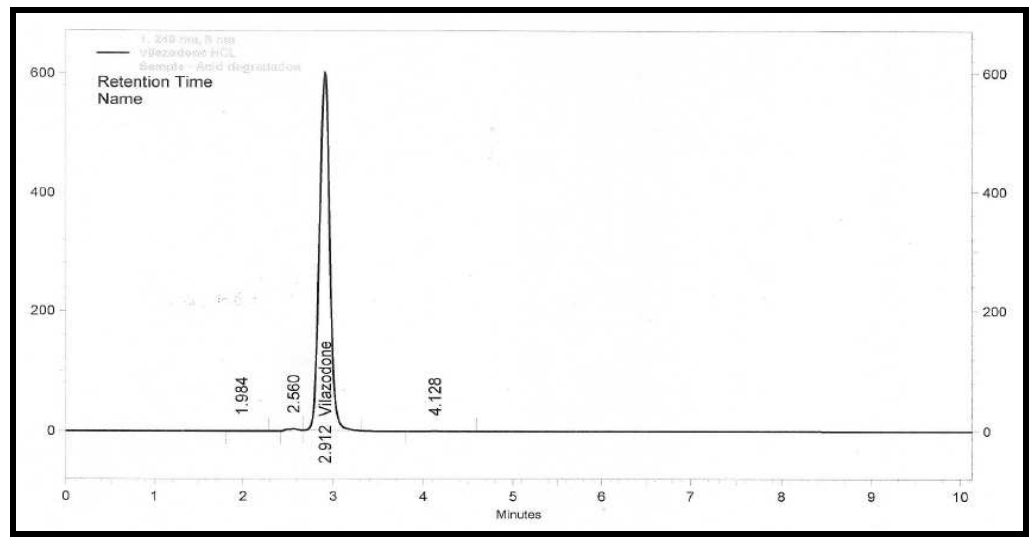

Fig. 5: Chromatogram of vilazodone hydrochloride in acidic degradation condition $(50 \mu \mathrm{g} / \mathrm{ml})$

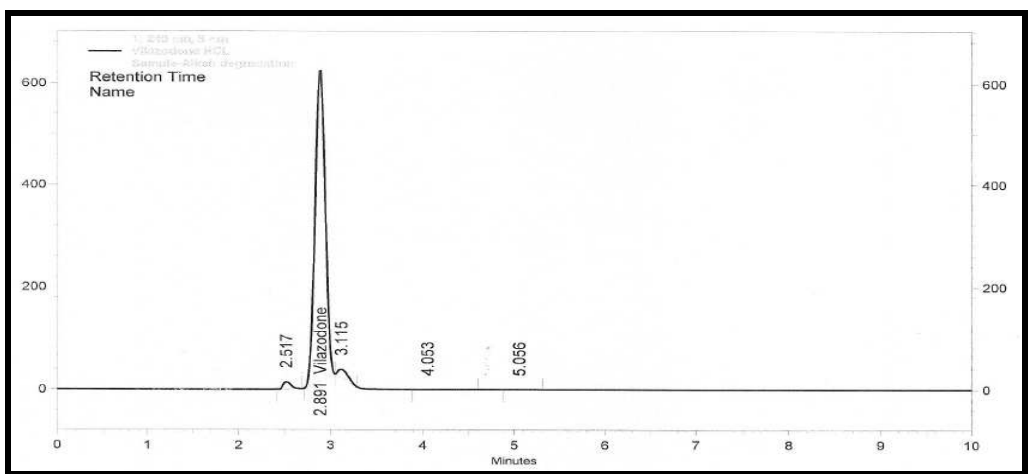

Fig. 6: Chromatogram of vilazodone hydrochloride in alkaline degradation condition $(50 \mu \mathrm{g} / \mathrm{ml})$

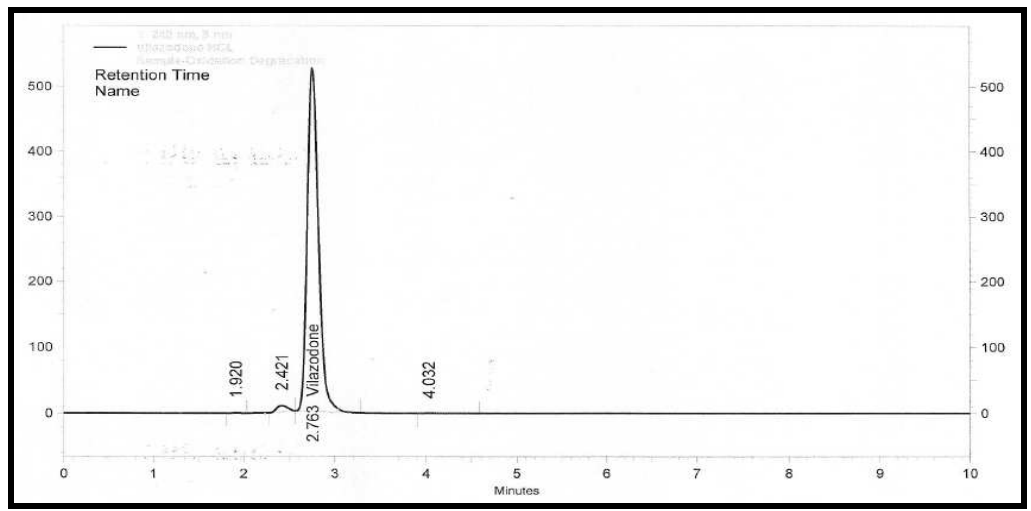

Fig. 7: Chromatogram of vilazodone hydrochloride in oxidative degradation condition $(50 \mu \mathrm{g} / \mathrm{ml})$

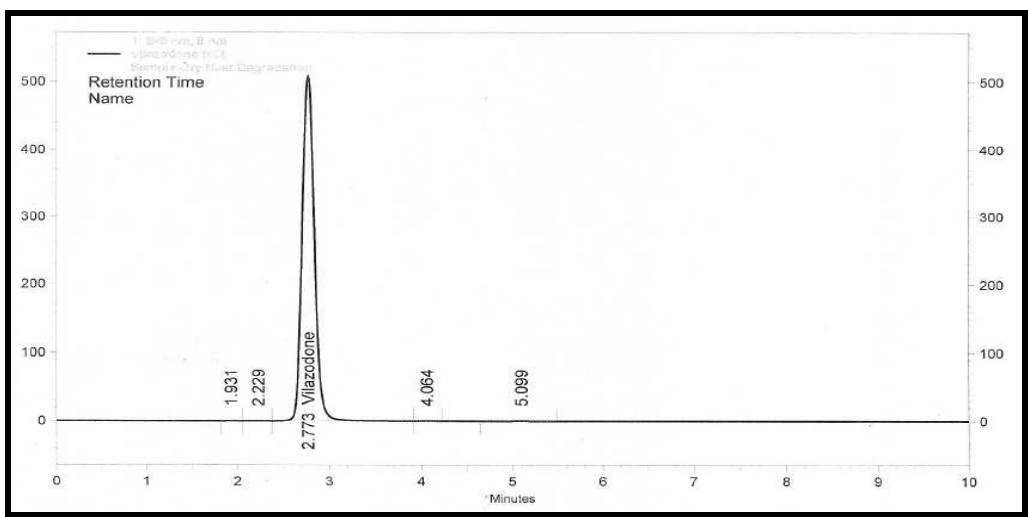

Fig. 8: Chromatogram of vilazodone hydrochloride in thermal degradation condition $(50 \mu \mathrm{g} / \mathrm{ml})$ 


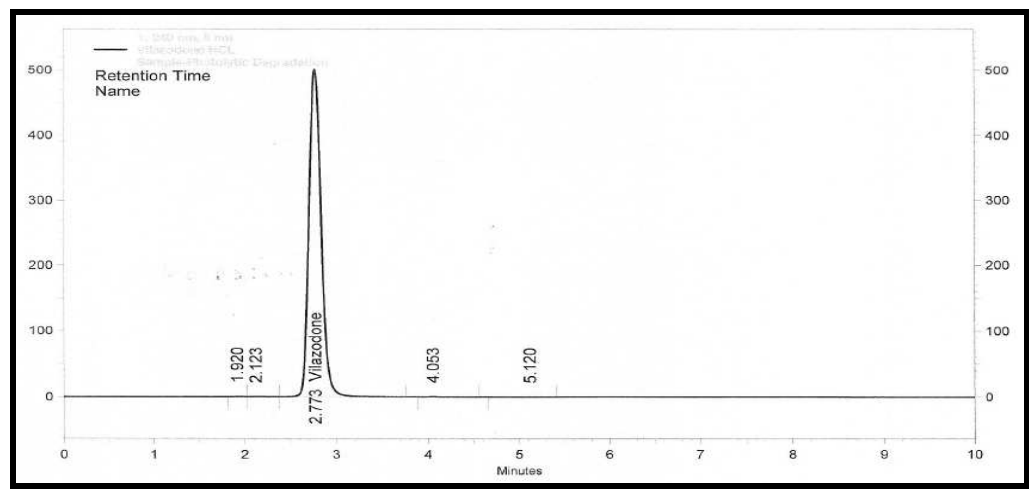

Fig. 9: Chromatogram of vilazodone hydrochloride in photolytic degradation condition $(50 \mu \mathrm{g} / \mathrm{ml})$

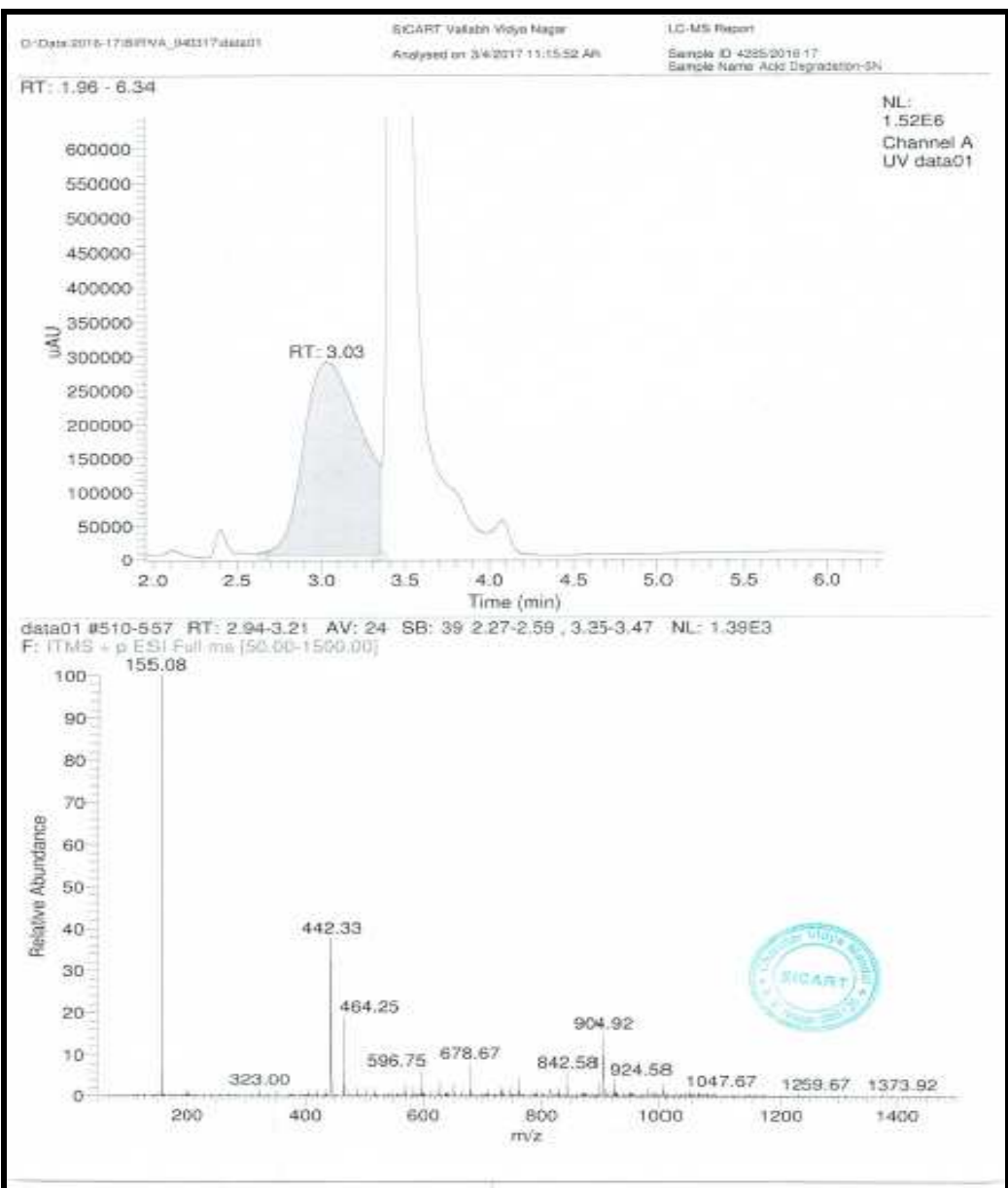

Fig. 10: LC-MS/MS spectrum of vilazodone hydrochloride in acid degradation condition at retention time 3.03 min

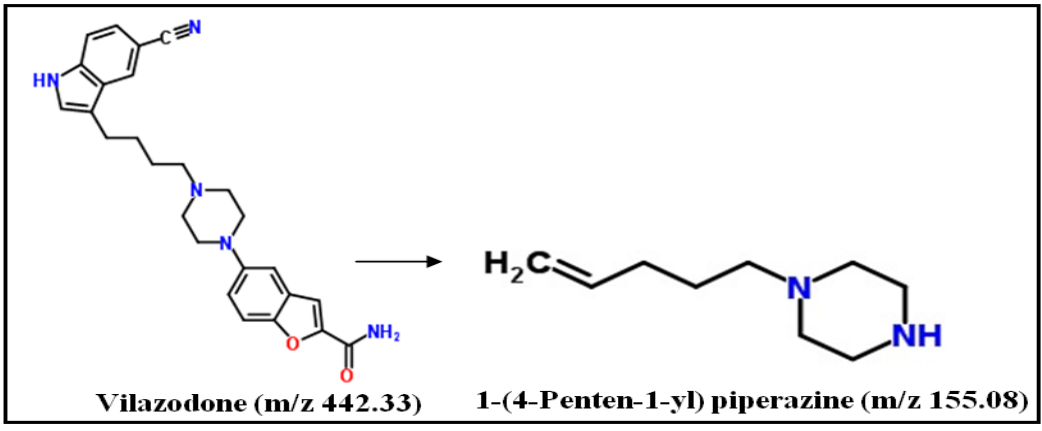

Fig. 11: Acid degradant of vilazodone hydrochloride 


\section{CONCLUSION}

The proposed HPLC method was developed and validated according to ICH Guidelines and was found to be precise, accurate and stability indicating. The proposed method was successfully applied for the estimation of Vilazodone Hydrochloride in Marketed Tablet Formulation. The method can also be used for determining the drug purity by being able to detect related impurities. The method can be used in small laboratories with very high accuracy and also can save much time and money.

\section{ACKNOWLEDGEMENT}

The author would like to thank SYMED LABS LTD for providing the gift sample of Vilazodone Hydrochloride. The author would also like to thank the Bhagwan Mahavir College of Pharmacy, Surat and SICART, Vallabh Vidyanagar for providing facilities to carry out research work.

\section{CONFLICT OF INTERESTS}

Declare none

\section{REFERENCES}

1. Tripathi KD. Essentials of medical pharmacology. $6^{\text {th }}$ ed. Jaypee Brothers Medical Publishers, New Delhi; 2008. p. 405-18.

2. https://www.drugs.com/monograph/vilazodonehydrochloride.html [Last accessed on 20 Dec 2017]

3. Reddy PB, Pramod N, Venkateshwararao P, Sudhakar babu AMS. Method development and validation for the assay of vilazodone in bulk and formulation by using RP-HPLC. Int J Biol Pharm Res 2012;3:789-95.

4. Gosh S, Venkatesh S, Ravikumar BVV. Development of stability indicating RP-HPLC method and validation for the estimation of vilazodone hydrochloride. Int J PharmTech Res 2015;7:204-11.

5. Ravishankar P, Gowthami S, Devanshu CH, Shrinivas Babu P, Reddy PV. A novel validated RP-HPLC method for the estimation of vilazodone in bulk and pharmaceutical dosage form. Am J PharmTech Res 2014;4:670-82.

6. Venkata SG, Devika GS, Salibai R, Hemalatha K. Determination of vilazodone in pharmaceutical formulations by HPLC method. J Global Trends Pharm Sci 2014;5:2261-64.

7. Thangabalan B, Lakshmi NR, Syedali Fathima SK, Manohar Babu S. UV Spectrophotometric estimation of Vilazodone in pure and tablet dosage form. Asian J Pharm Res 2015;5:126-7.
8. Damle MC, Agrawal AA. Development and validation of stability indicating HPTLC method for estimation of vilazodone hydrochloride. Int J Pharm Res Scholars 2015;4:262-8.

9. Kalariya PD, Talluri MVNK, Patel PN, Shrinivas R. Identification of hydrolytic and isomeric $\mathrm{N}$-oxide degradants of vilazodone by online LC-ESI-MS/MS and APCI-MS. J Pharm Biomed Anal 2015;102:353-65.

10. Marwa F, Ramzia EB, Hanaa H, Tarek S. UPLC-MS/MS method for the determination of vilazodone in human plasma: application to a pharmaceutical study. J Diagnos Tech Biomed Anal 2015;3:118.

11. Sui W, Yang X, Yu W, Jin Yi, Luan X, Wang X, et al. A validated LC-MS/MS method for the rapid quantification of vilazodone in rat plasma: application to a pharmacokinetic study. J Pharm Biomed Anal 2014;98:228-34.

12. Kalariya PD, Talluri MVNK, Shrinivas R. Experimental design approach for selective separation of vilazodone $\mathrm{HCl}$ and its degradants by LC-PDA and characterization of major degradants by LC/QTOF-MS/MS. J Chromatogr 2014;17:1299-313.

13. Dedania ZR, Dedania RR, Sheth NR, Gajra B, Patel J. Development and validation of stability-indicating high performance liquid chromatography assay for aripiprazole in bulk drug substance. Asian J Pharm Biol Res 2011;1:123-8.

14. Dedania ZR, Dedania RR, Sheth NR. Stability indicating HPLC determination of quetiapine fumarate. Int J Pharm Sci Res 2013;4:2406-14.

15. Dedania ZR, Dedania RR, Sheth NR, Patel JB, Patel B. Stability indicating HPLC determination of risperidone in bulk drug and pharmaceutical formulations. Int J Anal Chem 2011:1-7. http://dx.doi.org/10.1155/2011/124917

16. ICH Harmonized Tripartite Guideline. Validation of Analytical Procedures: Text and Methodology Q2 (R1), International Conference on Harmonization, Geneva: Switzerland; 2005. p. 1-13.

17. Q1 R2: Stability Testing of New Drugs and products, International Conference on Harmonization of Technical Requirements For Registration of Pharmaceuticals for Human Use, ICH Harmonised Tripartite Guideline; 2003. p. 1-18.

\section{How to cite this article}

- $\quad$ Birva A Athavia, Zarna R Dedania, Ronak R Dedania, SM Vijayendra Swamy, Chetana B Prajapati. Stability indicating HPLC method for determination of vilazodone hydrochloride. Int J Curr Pharm Res 2017;9(4):123-129. 